\title{
Cost-effectiveness of animal protein consumption in Turkey
}

\section{Mehmet Ferit Can ${ }^{1} @$ Hayriye Yeşim Can $^{2 *} \odot$}

${ }^{1}$ Department of Animal Health Economics and Management, Faculty of Veterinary Medicine, Hatay Mustafa Kemal University, 31060, Hatay, Turkey. ${ }^{2}$ Department of Food Hygiene and Technology, Faculty of Veterinary Medicine, Hatay Mustafa Kemal University, Hatay, Turkey. E-mail: yesimcan@mku.edu.tr. "Corresponding author.

ABSTRACT: The most tangible economic indicator of animal protein consumption is the real price of $1 \mathrm{~g}$ protein of a certain quality. The present study aimed to determine and compare the cost-effectiveness of some animal proteins in Turkey. To determine cost-effectiveness, average protein contents $(\mathrm{g} / 100 \mathrm{~g}$ ), biological values (\%), and inflation-adjusted 36-month real prices (TRY/kg) of eight different foods of animal origin were used. The ANOVA test yielded a significant difference between the cost-effectiveness of selected animal proteins $(P<0.01$ and $\eta 2=0.973$ ). Multiple comparisons revealed that chicken meat and chicken egg, between which there was no significant difference, were economically superior to other foods $(P<0.05)$. Cow's milk and homogenized yogurt, between which there was no significant difference, took second place in terms of cost-effectiveness. These products were followed by fresh kashar cheese, ripened Turkish white cheese, beef meat, and mutton meat. There were also significant relationships between the unit prices of certain animal products. Although the real price of $1 \mathrm{~g}$ of animal protein varies according to time and place depending on the factors affecting supply and demand, the global economic advantage of egg and chicken meat coincides with the dimensions of health and religious beliefs. If today's demographic, climatic, biological, and technological developments can make animal protein production cheaper and more reliable, consumer welfare in underdeveloped and developing countries can increase.

Key words: animal, biological value, economic, food, protein content.

Custo-efetividade do consumo de proteína animal na Turquia

RESUMO: O indicador econômico mais tangivel do consumo de proteína animal é o preço real de $1 \mathrm{~g}$ de proteína de determinada qualidade. O presente estudo teve como objetivo determinar e comparar o custo-efetividade de algumas proteinas animais na Turquia. Para determinar a relação custo-benefício, foram utilizados os teores de proteina (g/100 g), valores biológicos (\%) e preços reais de 36 meses (TRY/kg), ajustados pela inflação, de oito diferentes alimentos de origem animal. O teste ANOVA rendeu uma diferença significativa entre o custo-efetividade das proteinas animais selecionadas $(P<0,01$ e $\eta 2=0,973)$. Múltiplas comparações revelaram que a carne de frango e o ovo de galinha, entre os quais não houve diferença significativa, foram economicamente superiores aos outros alimentos $(P<0,05)$. O leite de vaca e o iogurte homogeneizado, entre os quais não houve diferença significativa, ficaram em segundo lugar em termos de custo-beneficio. Esses produtos foram seguidos por queijo kashar fresco, queijo branco turco curado, carne bovina e carne de carneiro. Também havia relações significativas entre os preços unitários de certos produtos de origem animal. Embora o preço real de $1 \mathrm{~g}$ de proteína animal varie de acordo com o tempo e o local, dependendo dos fatores que afetam a oferta e a demanda, a vantagem econômica global do ovo e da carne de frango coincide com as dimensões da saúde e das crenças religiosas. Contudo, se os desenvolvimentos demográficos, climáticos, biológicos e tecnológicos de hoje podem tornar a produção de proteína animal mais barata e mais confível, o bem-estar do consumidor em países subdesenvolvidos e em desenvolvimento pode aumentar.

Palavras-chave: animal, valor biológico, econômico, alimento, teor de proteina.

\section{INTRODUCTION}

A healthy, adequate, and balanced diet is only possible with sufficient intake of proteins through diet. The recommended daily intake of protein for adults varies between 0.8 and $1.6 \%$ (average $1 \%$ ) of body weight, depending on age, physical activity, and physiological status. Since animal proteins are superior to plant proteins in many respects, at least half of the total protein requirement should be provided with foods of animal origin with higher biological values. Today, the share of animal proteins in total protein intake in Europe and America is around $60-70 \%$, whereas this rate is still below $50 \%$ in Asia, Africa, and the world in general (MURPHEY \& ALLEN, 2003; BERNER et al., 2013; KIM et al., 2015; ROZENBERG et al., 2016; BERRAZAGA et al., 2019; FAO, 2020). Since insufficient production,

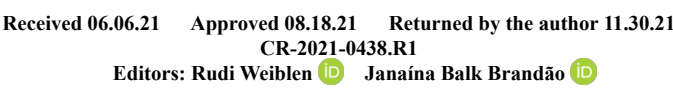


high prices, and low purchasing power play an important role in animal protein deficiency, it is important for consumers to choose alternative animal protein sources based on the principle of "economic rationality".

Today, there are billions of people around the world who lack even minimal access to animal protein sources. The pressure of climate change and unplanned urbanization on land and water resources, inadequate information technologies, insufficient production due to terrorism and epidemics, and income inequality put global food security at risk (FAO, 2020; ISMAIL et al., 2020). In addition, access to animal protein can be a problem not only in underdeveloped countries but also for lower socioeconomic groups and the elderly population in developed countries (BERNER et al., 2013). Indeed, these problems have been further highlighted with the COVID-19 pandemic with its destructive effects, which has made the production and distribution of basic foods more vital (HART et al., 2020). These developments, in turn, have led to global discussions about access to cheap and healthy protein sources and economic rationality in animal protein consumption.

Consumption preferences for animal products are affected by product prices as well as consumers' income level, health status, educational background, age, gender, and dietary habits (MCCARTHY et al., 2004; WILCOCK et al., 2004; CAN et al., 2015). It is actually hard to say that one animal product is superior to another. However, "health" and "economy" are more objective criteria than other criteria in food preferences. Considering that consumers have different health statuses and given the presence of conflicting reports about the risks and advantages of certain foods, it can be said that the "unit price of animal protein of a particular quality" is almost the most tangible criterion. It is emphasized that protein sources should be assessed not only biologically but also in terms of costeffectiveness and market demands (ISMAIL et al., 2020). All these approaches lead us directly to the concept of "cost-effectiveness."

The concept of cost-effectiveness is used in many cost-benefit relationships, especially in the healthcare sector. Indeed, the principle of "achieving a certain benefit at the lowest cost" can be adapted to cost-effectiveness in protein consumption as well (CALDWELL et al., 2007; BORNER \& WUNDER, 2012). The reason for choosing the term "costeffectiveness" rather than "the cheapest" in this study is that the unit protein, which provides net benefits to consumers, should have a "certain quality" so that alternative sources can be compared correctly.
The cost-effectiveness of $1 \mathrm{~g}$ of animal protein of a certain quality can be calculated by using the total amount of protein in the food product, the biological quality of the protein and the unit price of the product. The total amount of protein in foods of animal origin is usually expressed as the total protein content as grams in $100 \mathrm{~g}$ of food (ROZENBERG et al., 2016; MOHAMMED et al., 2020). On the other hand, the quality of protein is determined by assessing its essential amino acid composition and the bioavailability and digestibility of amino acids. Net protein utilization (NPU) and biological value (BV) are widely employed in the measurement of these criteria. Though these two terms are generally used to mean the same thing, there is, in fact, a slight difference between them. BV refers to the proportion of absorbed protein, whereas NPU is the percentage of digested nitrogen (HOFFMAN \& FALVO, 2004; BERRAZAGA et al., 2019). Since, in the living body, absorption occurs after digestion and the final benefit from the foods that enter the blood is obtained at this stage, BV was preferred in this study.

Turkey's per capita consumption of animal products is close to the average of developed countries, except for red meat, fish, and milk. However, the high food inflation, especially in recent years, and the relatively low per capita national income compared to developed countries have made the concept of costeffectiveness more important in Turkey (CAN et al., 2015; CAN, 2018; OZEN et al., 2019; TURKSTAT, 2021a, b). No study has so far been conducted in Turkey on the cost-effectiveness of animal proteins of a certain quality, and the number of international studies on the subject is quite limited.

Taking these as a starting point, the present study aimed to determine and compare the costeffectiveness of unit proteins of selected animal proteins in Turkey. The results of the research are expected to contribute to decision-makers involved in increasing consumer welfare and directing production.

\section{MATERIALS AND METHODS}

\section{General framework}

In this study, the cost-effectiveness of the unit protein of eight different animal products most consumed in Turkey was investigated. To this end, red meat and chicken meat, milk and some dairy products, and chicken eggs, whose price series can be reached reliably, were taken into consideration. Since there are lots of fish species and the fish price is affected significantly by seasonal price changes, and as pork is mainly consumed by foreign tourists in 
Turkey, fish and pork were not included in the scope of the study. To determine the cost-effectiveness of food products, mathematical equations were established with biological, technical, and economic data. For this purpose, first of all, the protein content and biological value of each animal product were determined. Then, 36-month current prices of each product were converted into 2018 real prices with the help of indices reported institutionally. Finally, the unit real prices of each animal protein of a certain quality were calculated and statistically compared. Univariate relationships between selected animal products were also examined with the aim of better understanding the unit price patterns.

\section{Data used and parameter considered}

Animal foods selected in the study are as follows: whole cow's milk (I), ripened Turkish white cheese from cow's milk (II), fresh kashar cheese (III), whole-fat homogenized yogurt made from cow's milk (IV), beef meat (V), mutton meat (VI), industrial chicken meat (VII), and industrial chicken egg (VIII). Average protein contents (g/100 g) and biological values $(\%)$ of these products given in table 1 were obtained from scientific literature, the national database (Turkish Food Composition Database), and institutional report (HOFFMAN \& FALVO, 2004; TEKINSEN \& TEKINSEN, 2005; HAUG et al., 2007; PELLEGRINO et al., 2013; ROZENBERG et al., 2016; ISMAIL et al., 2020; MOHAMMED et al., 2020; TURKOMP, 2021).

\section{Calculation of cost-effectiveness}

Current prices of selected animal products are the 36-month average retail prices reported by relevant producer organizations (SETBIR, 2020; TEPGE, 2020; YUMBIR, 2021). Animal products with local characteristics and relatively low consumption and without reliable price series were excluded from the scope of the study. To compare cost-effectiveness in a statistically accurate manner, first, monthly price series were converted into real prices (AYDIN et al., 2011). To this end, the price series of selected animal foods for the January 2018 - December 2020 period were adjusted for inflation with the help of the official monthly consumer price index (CPI) and reduced to January 1, 2018. Then, the unit cost of protein of a certain quality, namely its cost-effectiveness, was calculated (BORNER \& WUNDER, 2012; TURKSTAT, 2021a, b). Monthly reduced real prices (RRP) for each product were calculated as follows; $\sum_{\mathrm{n} P}^{36} \mathrm{CPI \textrm {k }}$
$\left.\mathrm{R} \mathrm{P}_{\mathrm{c}}\right)-\left[\left(\mathrm{P}_{\mathrm{c}}\right)^{*}\left(\frac{\sum_{k=0} \mathrm{CO}}{100}\right)\right]$ where " $n$ " denotes the relevant animal product, " $\mathrm{P}_{\mathrm{c}}$ " the current retail price of the product, "K" the base month, and "CPI" the monthly consumer price index change. As a result, real prices were calculated with the help of cumulative index changes.

The cost-effectiveness of each animal protein (CEAP) for one unit (1 g) protein was calculated as follows;

CEAP $_{n}=\frac{\text { RRP }}{(10 * \text { NPC } * \text { BV })}$

where " $n$ " denotes the relevant animal product, "NPC" the total protein content of 100 grams of the product, and "BV" the relative biological value of the relevant animal protein. The NPC value was first multiplied by 10 to calculate the protein amount of each product weighing $1 \mathrm{~kg}(1000 \mathrm{~g})$, and the result was again multiplied by the biological value (\%) of the relevant product to calculate the net product utilization. Finally, the RRP was divided by this result, and the cost of $1 \mathrm{~g}$ protein was calculated with the help of the Microsoft Excel 2013 software.

\section{Statistical analyses}

To test the data for conformance with normal distribution, the Shapiro-Wilk test was used, since the number of subjects in each data set was less than 50. One-Way ANOVA, one of the parametric tests, was used to assess the difference between the cost-effectiveness of animal proteins. Since Levene's test failed to yield homogeneity of variance, Games-Howell post-hoc test was used to determine the group that caused the difference. Effect size for ANOVA was evaluated using the partial eta-squared ( 2 ). Univariate relationships were examined using correlation coefficients. Statistical significance was set at $\mathrm{P}<0.05$ in multiple comparisons. Analyses were performed with Microsoft Excel and SPSS software (GILBERT, 1987; CORTINA \& NOURI, 2000; CAN, 2014; CAN et al., 2020).

\section{RESULTS}

Table 2 presents descriptive statistics for the real unit costs of eight different animal proteins. ANOVA results showed a significant difference between the cost-effectiveness of the selected products $(\mathrm{P}<0.01)$. A large effect size was also found between groups $(\eta 2=0.973)$. Multiple comparison tests were performed to determine which groups produced the difference (Table 3 ).

The results of multiple comparisons are summarized in table 3, together with the differences between means, statistical significance, and 
Table 1 - Protein contents and biological values of selected animal products.

\begin{tabular}{|c|c|c|}
\hline Parameters & Selected Foods of Animal Origin & Values \\
\hline \multirow{8}{*}{$\begin{array}{l}\text { A. Average protein } \\
\text { content }(\mathrm{g} / 100 \mathrm{~g})\end{array}$} & $\mathrm{A}_{1}$. Cow's milk & 3.3 \\
\hline & $\mathrm{A}_{2}$. Ripened Turkish white cheese from cow's milk & 16.1 \\
\hline & $\mathrm{A}_{3}$. Fresh kashar cheese & 26.9 \\
\hline & A 4 . Homogenized yogurt from cow's milk & 4.5 \\
\hline & $\mathrm{A}_{5}$. Beef meat & 20.6 \\
\hline & $\mathrm{A}_{6}$. Mutton meat & 21.5 \\
\hline & $\mathrm{A}_{7}$. Chicken meat & 22.7 \\
\hline & $\mathrm{A}_{8}$. Whole chicken egg & 13.1 \\
\hline \multirow{8}{*}{$\begin{array}{l}\text { B. Biological } \\
\text { Value (\%) }\end{array}$} & $B_{1}$. Cow's milk & 91 \\
\hline & $\mathrm{B}_{2}$. Ripened Turkish white cheese from cow's milk & 77 \\
\hline & $\mathrm{B}_{3}$. Fresh kashar cheese & 77 \\
\hline & $\mathrm{B}_{4}$. Homogenized yogurt from cow's milk & 90 \\
\hline & $\mathrm{B}_{5}$. Beef meat & 80 \\
\hline & $\mathrm{B}_{6}$. Mutton meat & 75 \\
\hline & B 7. Chicken meat & 79 \\
\hline & B $_{8}$. Whole chicken egg & 100 \\
\hline
\end{tabular}

confidence intervals. Statistical analyses revealed that "chicken meat and egg," between which there was no significant difference $(\mathrm{P}>0.05)$, differed significantly from other products $(\mathrm{P}<0.05)$. It was observed that the second cheapest source was "milk and yogurt," between which there was no significant difference in terms of cost-effectiveness. Mutton was found to be the most expensive source of protein among selected products $(\mathrm{P}<0.05)$.

The relationships between selected animal products are given in table 4 . Positive significant relationships were found between almost all unit prices of these products, except between the mutton and chicken meat.

\section{DISCUSSION}

Animal proteins are important not only for the amount and frequency of consumption but also for the price of the unit protein which the organism can utilize. The economic importance of proteins arises from not only the global animal protein deficiency but also from consumers' efforts to get the most benefit with their limited budgets. To develop a more holistic approach to the subject, it is necessary to investigate, first global and then Turkey-wide adequacy of animal protein consumption, animal production trends, animal product prices, and purchasing power and consumption preferences of consumers.

Table 2 - Descriptive statistics and ANOVA results for the cost-effectiveness of the products

\begin{tabular}{|c|c|c|c|}
\hline \multirow[t]{2}{*}{ Proteins of Animal Origin } & \multirow[t]{2}{*}{$\mathrm{N}$} & \multicolumn{2}{|c|}{------Reduced Price of $1 \mathrm{~g}$ of Protein (TRY)------ } \\
\hline & & $\mathrm{X} \pm \mathrm{SD}$ & Std. Error \\
\hline I. Cow's milk & 36 & $0.111 \pm 0.007$ & 0.001 \\
\hline II. Ripened Turkish white cheese from cow's milk & 36 & $0.165 \pm 0.132$ & 0.002 \\
\hline III. Fresh kashar cheese & 36 & 0.1300 .081 & 0.001 \\
\hline IV. Homogenized yogurt from cow's milk & 36 & $0.110 \pm 0.010$ & 0.001 \\
\hline V. Beef meat & 36 & $0.211 \pm 0.019$ & 0.003 \\
\hline VI. Mutton meat & 36 & $0.240 \pm 0.008$ & 0.001 \\
\hline VII. Chicken meat & 36 & $0.046 \pm 0.008$ & 0.001 \\
\hline VIII. Whole chicken egg & 36 & $0.042 \pm 0.008$ & 0.001 \\
\hline
\end{tabular}

Ciência Rural, v.52, n.9, 2022. 
Table 3 - The results of multiple comparisons for selected animal products (Games-Howell)

\begin{tabular}{|c|c|c|c|c|c|}
\hline \multicolumn{2}{|c|}{--'--'Groups and Comparisons-- } & \multirow[t]{2}{*}{ Mean Differences } & \multirow[t]{2}{*}{ Sig. } & \multicolumn{2}{|c|}{ 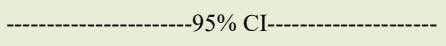 } \\
\hline & & & & Lower Bound & Upper Bound \\
\hline \multirow{7}{*}{ I. Cow's milk } & RTWC & -0.053 & * & -0.061 & -0.045 \\
\hline & FKC & -0.019 & * & -0.024 & -0.013 \\
\hline & HY & 0.001 & & -0.005 & -0.008 \\
\hline & Beef meat & -0.100 & * & -0.111 & -0.089 \\
\hline & Mutton meat & -0.128 & * & -0.134 & -0.122 \\
\hline & Chicken meat & 0.064 & ${ }^{*}$ & 0.059 & 0.070 \\
\hline & Chicken egg & 0.069 & * & 0.063 & 0.074 \\
\hline \multirow{7}{*}{$\begin{array}{l}\text { II. Ripened Turkish } \\
\text { white cheese from } \\
\text { cow's milk (RTWC) }\end{array}$} & Cow's milk & 0.053 & * & 0.045 & 0.061 \\
\hline & FKC & 0.034 & * & 0.026 & 0.042 \\
\hline & HY & 0.054 & * & 0.046 & 0.063 \\
\hline & Beef meat & -0.046 & * & -0.059 & -0.034 \\
\hline & Mutton meat & -0.075 & * & -0.083 & -0.066 \\
\hline & Chicken meat & 0.118 & * & 0.110 & 0.126 \\
\hline & Chicken egg & 0.122 & * & 0.114 & 0.130 \\
\hline \multirow{7}{*}{$\begin{array}{l}\text { III. Fresh kashar cheese } \\
\text { (FKC) }\end{array}$} & Cow's milk & 0.019 & * & 0.013 & 0.024 \\
\hline & RTWC & -0.034 & * & -0.042 & -0.026 \\
\hline & HY & 0.020 & $*$ & 0.013 & 0.027 \\
\hline & Beef meat & -0.080 & * & -0.092 & -0.069 \\
\hline & Mutton meat & -0.109 & * & -0.115 & -0.103 \\
\hline & Chicken meat & 0.083 & $*$ & 0.079 & 0.090 \\
\hline & Chicken egg & 0.088 & * & 0.081 & 0.094 \\
\hline \multirow{7}{*}{$\begin{array}{l}\text { IV. Homogenized } \\
\text { yogurt from cow's milk } \\
(\mathrm{HY})\end{array}$} & Cow's milk & -0.001 & & -0.008 & -0.005 \\
\hline & RTWC & -0.054 & $*$ & -0.063 & -0.046 \\
\hline & FKC & -0.020 & * & -0.027 & -0.013 \\
\hline & Beef meat & -0.101 & * & -0.113 & -0.089 \\
\hline & Mutton meat & -0.130 & $*$ & -0.137 & -0.122 \\
\hline & Chicken meat & 0.063 & * & 0.056 & 0.070 \\
\hline & Chicken egg & 0.067 & $*$ & 0.060 & 0.074 \\
\hline \multirow{7}{*}{ V. Beef meat } & Cow's milk & 0.100 & * & 0.089 & 0.111 \\
\hline & RTWC & 0.046 & * & 0.034 & 0.059 \\
\hline & FKC & 0.080 & * & 0.069 & 0.092 \\
\hline & HY & 0.101 & * & 0.089 & 0.113 \\
\hline & Mutton meat & -0.028 & * & -0.039 & -0.017 \\
\hline & Chicken meat & 0.164 & $*$ & 0.153 & 0.176 \\
\hline & Chicken egg & 0.169 & * & 0.157 & 0.180 \\
\hline \multirow{7}{*}{ VI. Mutton meat } & Cow's milk & 0.128 & * & 0.122 & 0.134 \\
\hline & RTWC & 0.075 & $*$ & 0.066 & 0.083 \\
\hline & $\mathrm{FKC}$ & 0.109 & * & 0.103 & 0.115 \\
\hline & HY & 0.130 & $*$ & 0.122 & 0.137 \\
\hline & Beef meat & 0.028 & $*$ & 0.017 & 0.039 \\
\hline & Chicken meat & 0.193 & * & 0.187 & 0.199 \\
\hline & Chicken egg & 0.197 & $*$ & 0.191 & 0.204 \\
\hline \multirow{7}{*}{ VII. Chicken meat } & Cow's milk & -0.064 & * & -0.070 & -0.059 \\
\hline & RTWC & -0.118 & * & -0.126 & -0.110 \\
\hline & FKC & -0.083 & * & -0.090 & -0.077 \\
\hline & HY & -0.063 & $*$ & -0.070 & -0.056 \\
\hline & Beef meat & -0.164 & * & -0.176 & -0.153 \\
\hline & Mutton meat & -0.193 & * & -0.199 & -0.187 \\
\hline & Chicken egg & 0.004 & & -0.02 & 0.010 \\
\hline \multirow{7}{*}{ VIII. Chicken egg } & Cow's milk & -0.069 & $*$ & -0.074 & -0.063 \\
\hline & RTWC & -0.122 & * & -0.130 & -0.114 \\
\hline & FKC & -0.088 & * & -0.094 & -0.081 \\
\hline & HY & -0.067 & * & -0.074 & -0.060 \\
\hline & Beef meat & -0.169 & * & -0.180 & -0.157 \\
\hline & Mutton meat & -0.197 & * & -0.204 & -0.191 \\
\hline & Chicken meat & -0.004 & & -0.010 & 0.002 \\
\hline
\end{tabular}


Before addressing these important subheadings, it is necessary to mention the strengths and weaknesses of this study. To put it briefly, the most positive aspect of this study is that the rationality of unit animal protein consumption was determined by the combination of economic and biological data. This is a new and novel approach to assess net consumer welfare. If we look at negative aspects, one of them is that reliable price series are available only for some products and for a limited time period in most of the country. Although the costeffectiveness varies depending on time and place due to the supply-demand balance, we believe that the right methodological approach provides valuable information on consumer welfare no matter what part of the world.

Today, more than $90 \%$ of the 673 million malnourished people in the world live in Africa and Asia. The total amount of protein consumed per capita per day in 2017 was $105 \mathrm{~g}$ for North America and Europe, and $63 \mathrm{~g}$ for Africa. This big difference is due to the lack of animal proteins, not plant proteins (FAO, 2020). Although at least half of the total protein consumed is recommended to be from foods of animal origin, the share of plant-based proteins in people's diet in Africa, Asia, Latin America, North America, and Europe is $78 \%, 66 \%, 49 \%, 41 \%$, and $36 \%$, respectively (KIM et al., 2015; BERRAZAGA et al., 2019; FAO, 2020). A study conducted in the USA reported that meat and milk accounted for $62 \%$, plant-based proteins $30 \%$, and the remaining unclassified products $8 \%$ in total protein consumed (PASIAKOS et al., 2015). In Turkey, the total daily protein supply and animal protein supply per capita for the 2015-17 period were reported as $101 \mathrm{~g}$ and 35 g, respectively (FAO, 2020). If a detailed calculation is made taking into account the total population, total animal production, and protein contents and biological values of products, it will be seen that the daily animal protein supply per capita in Turkey is around 45-50 g (CAN et al., 2015; SACLI \& OZER, 2017; FAO, 2020). Hence, it can be said that adults with normal physical activity in Turkey meet half of their daily average protein needs $(\approx 75 \mathrm{~g}$ per $75 \mathrm{~kg}$ live weight) from animal foods. In Turkey, consumption of only some animal products such as red meat, fish, and milk is less than in developed countries. The reason for this is high input costs and inflation for red meat and consumption habits, and seasonal characteristics of supply for milk and fish (CAN et al., 2015; CAN, 2018; OZEN et al., 2019; TURKSTAT, 2021b). Doubtlessly, there are many technological, economic, and political solutions to eliminating protein deficiency. Perhaps the most interesting of these solutions is artificial (in vitro) meat production. However, this current issue is still controversial in terms of ethics and rural sociology (LEE et al., 2020; SUREK \& UZUN, 2020).

"Prices of animal products" and "food inflation" are key indicators of consumer welfare. Today, unit retail prices of animal products vary geographically. The main reasons for this are the differences between climates, populations, technologies, producer organizations, food supply chains, and livestock policies of countries. The food inflation index, which is very important for consumer welfare, is in the $0-5 \%$ range in developed countries, but well above $5 \%$ in developing and underdeveloped countries. The average change in the consumer food price index for the last 20 years in the USA has been reported as $2 \%$ in poultry meat and dairy products, $3 \%$ in egg, and $4 \%$ in beef. These rates in Turkey have been several times those in the USA for the last few years and are even above the world and Africa average (FAO, 2020; TURKSTAT, 2021a; USDA,

Table 4 - The mutual relationships between selected animal products.

\begin{tabular}{|c|c|c|c|c|c|c|c|c|}
\hline \multirow[t]{2}{*}{ Groups } & \multicolumn{8}{|c|}{ 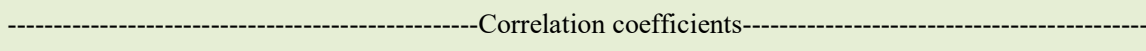 } \\
\hline & I & II & III & IV & $\mathrm{V}$ & VI & VII & VIII \\
\hline I. Cow's milk & 1.000 & $0.856^{* *}$ & $0.853^{* *}$ & $0.849^{* *}$ & $0.521^{* *}$ & 0.290 & 0.170 & -0.187 \\
\hline II. RTWC & $0.856^{* *}$ & 1.000 & $0.957^{* *}$ & $0.944^{* *}$ & $0.642^{* *}$ & 0.249 & 0.226 & -0.026 \\
\hline III. FKC & $0.853^{* *}$ & $0.957^{* *}$ & 1.000 & $0.894^{* *}$ & $0.533^{* *}$ & 0.203 & 0.145 & 0.024 \\
\hline IV. HY & $0.818^{* *}$ & $0.912^{* *}$ & $0.901^{* *}$ & 1.000 & $0.620^{* *}$ & 0.272 & $0.359^{*}$ & -0.002 \\
\hline V. Beef meat & $0.521^{* *}$ & $0.642^{* *}$ & $0.533^{* *}$ & $0.620^{* *}$ & 1.000 & $0.659^{* *}$ & $0.515^{* *}$ & -0.326 \\
\hline VI. Mutton meat & 0.290 & 0.249 & 0.203 & 0.272 & $0.659^{* *}$ & 1.000 & $0.396^{*}$ & $-0.346^{*}$ \\
\hline VII. Chicken meat & 0.170 & 0.226 & 0.145 & $0.359^{*}$ & $0.515^{* *}$ & $0.396^{*}$ & 1.000 & -0.220 \\
\hline VIII. Chicken egg & -0.187 & -0.026 & 0.024 & -0.002 & -0.326 & $-0.346^{*}$ & -0.220 & 1.000 \\
\hline
\end{tabular}

${ }^{*} \mathrm{P}<.05 ;{ }^{* *} \mathrm{P}<.01$ 
2021). Achieving price stability in animal products is also closely related to countries' agricultural policies. It is known that financial incentives and subsidies given by developed countries for decades increase productivity per animal, create a global cost advantage for producers and exporters, and serve consumer welfare (GLAUBER \& EFFLAND, 2016; CAN, 2018). On the other hand, high production costs, dysfunctional producer organizations, weak producer-industrialist integration, and high food inflation in Turkey negatively affect producers and consumers (GUNLU, 2011; CAN, 2014; FAO, 2020). The import of cheap animal products for the short-term benefit of consumers harms all sector stakeholders in the medium and long term (AYDIN et al., 2011; CAN, 2018).

Another important economic indicator of animal protein consumption is the purchasing power of consumers. In this context, the real minimum wage (RMW), which takes consumer price indices and purchasing power into account, is a global and objective indicator. In 2019, RMW was reported as $\$ 24015, \$ 15080, \$ 14060, \$ 5000, \$ 4967$, and \$ 2510 for Germany, the USA, Turkey, Russia, Brazil, and Mexico, respectively (OECD, 2021). Even though these figures are much higher than the average minimum wage, they are meaningful as they show the real purchasing power in each country. However, as RMW covers all goods and services, it may not give a clear idea about animal products. For example, according to the average retail prices in 2020, an American minimum wage employee could buy $113 \mathrm{~kg}$ of beef and $357 \mathrm{~kg}$ of chicken meat, while a Turkish minimum wage employee could buy $45 \mathrm{~kg}$ and $186 \mathrm{~kg}$, respectively (SETBIR, 2020; BLS, 2021; YUMBIR, 2021). Nevertheless, it is more appropriate to look at the budget that has remained for food after all other needs have been met. Finally, as informal employment in the agricultural sector and the COVID-19 pandemic halted or reduced real increases in minimum wages, the situation of producers and consumers may be worse than it appears (ILO, 2020).

This study provides some global recommendations on the economic dimension of animal protein consumption, while, by its very nature, it has some local limitations. This is because while the protein content and biological value of a selected animal product do not vary geographically, current and real prices vary significantly depending on the region and country. Nevertheless, the economic superiority of chicken meat and egg is globally acknowledged, as is proven by the results of this study (SCHMIER et al., 2009; IANNOTTI et al., 2014; FAO, 2020; TURKSTAT, 2021a; USDA, 2021). The upward production trend that has been observed for years for chicken meat and eggs in Turkey and for chicken meat and pork in the world supports these reports. For example, pork and chicken meat have a $35 \%$ and $33 \%$ share, respectively, in the total world meat production in 2018. While pork was the most produced meat in China, France, and Germany, chicken was the most produced meat in the USA, Russian Federation, and Turkey (BERNER et al., 2013; FAO, 2020; TURKSTAT, 2021b). Despite the negative effects of the COVID-19 pandemic on global production, import, and export, chicken meat consumption is expected to increase in the world. In 2018 , Turkey contributed by approximately $1.8 \%$ and $1.5 \%$ to the total global production of 114 million tons of chicken meat and 77 million tons of eggs, respectively (TEPGE, 2020). Chicken meat, egg, yogurt, and cheese are the most preferred foods of animal origin in Turkey, while beef, poultry meat, low-fat milk, cheese, and milk desserts are the most preferred in the USA (BERNER et al., 2013; PASIAKOS et al., 2015; SACLI \& OZER, 2017; TURKSTAT, 2021a).

In this study, there were two main selection criteria of foods of animal origin. The first was their widespread consumption, and the second was reliable access to retail price series. Therefore, we selected eight different animal products most consumed (whole cow's milk, ripened Turkish white cheese from cow's milk, fresh kashar cheese, whole-fat homogenized yogurt made from cow's milk, beef meat, mutton meat, industrial chicken meat, and industrial chicken egg) in Turkey. Fish was excluded from the study because there are lots of fish species and their price is affected significantly by seasonal price changes. Furthermore, due to Islamic ban on the consumption of pork, Islam is the largest religion in Turkey with $99 \%$, it was not included to the study (CAN et al., 2015; SACLI \& OZER, 2017; TAYAR \& DOGAN, 2019; TURKSTAT, 2021a).

In Turkey, the animal foods that offer $1 \mathrm{~g}$ of protein at the cheapest price are "chicken meat" and "chicken eggs," between which there is no difference in cost-effectiveness. Indeed, there are studies and reports consistent with this finding (SCHMIER et al., 2009; IANNOTTI et al., 2014; FAO, 2020; USDA, 2021). In Turkey, these products are followed by cow's milk, yogurt, fresh kashar cheese, ripened Turkish white cheese, beef meat, and mutton meat, respectively. Calculations made with the average current prices of 2020 showed that the price of unit protein provided from chicken meat and egg is three times cheaper in the USA and four times cheaper in Turkey than beef meat (SETBIR, 2020; BLS, 2021; YUMBIR, 2021). The rich 
biological content (essential amino acids and fatty acids, proteins, vitamins, etc.) and the low price of eggs make them almost unrivalled sources of animal protein worldwide. It is emphasized that the increase in egg production and consumption can lead to not only health benefits but also economic and social. Chicken meat is relatively more likely to carry some foodborne pathogens than eggs as a result of crosscontamination in the production process and cutup line, which can be a disadvantage for chicken meat (SCHMIER et al., 2009; IANNOTTI et al., 2014; MAHARJAN et al., 2019). Similarly, a study conducted in New Zealand reported that chicken meat offered less advantage in terms of unit cost than some processed meat products, and that only fresh chicken meat was more economical than frozen chicken meat (WILSON et al., 2007). In addition, if the upward trend in the prices of chicken meat observed in early 2021 in Turkey becomes permanent, the economic odds can be in favour of eggs. After deducting the exported amount, chicken meat $(\approx 21 \mathrm{~kg})$ and eggs $(\approx 13 \mathrm{~kg})$ have a large share in the amount of animal protein produced per capita in Turkey; therefore, it can be said that the consumption of animal protein in Turkey is in line with economic rationality (CAN et al., 2015; TEPGE, 2020; TURKSTAT, 2021a). Another noteworthy finding of this study is that milk, which is an indispensable food source, and yogurt, which is frequently consumed in Turkey, are more economical than cheese. However, since there are more than 1000 different types of cheese around the world, one should avoid making a generalization for protein consumption by considering only two types of cheese used in this study (FOX, 1993). Another finding of this study was the relationship between the unit prices. Positive significant relationships between almost all unit prices of these products cannot be explained by the combined effect of inflation alone. These relationships also indicate that substitution among these protein sources have been maintained over the period of 3 years considered for this study.

Financial and socioeconomic factors significantly affect consumption preferences of animal foods. Yet, this does not show that consumption is entirely based on economic rationality. Health, culture, beliefs, and habits also affect consumption, which is in line with the phenomenon of behavioural economics (MCCARTHY et al., 2004; WILCOCK et al., 2004; SMITH 2005; CAN et al., 2015). From the perspective of religious beliefs, the absence of a religious restriction on the consumption of poultry means an advantage in its consumption while the Islamic ban on the consumption of pork brings a disadvantage in its (SANTCHURN \& COLLIGNAN, 2007; TAYAR \& DOGAN, 2019). From the perspective of "health," aspects that contradict and overlap with "economy" can be noticed. For example, the rich biological content of chicken meat and eggs coincides with the cost-effectiveness of these products. However, the risk of contamination by foodborne pathogens such as Salmonella and Campylobacter contrasts with the economic advantages of, particularly, chicken meat (WILSON et al., 2007; IANNOTTI et al., 2014). Another example is milk and yogurt, which are highly important for development and growth, are easy to digest, and do not carry the risk of causing cardiovascular diseases (ROZENBERG et al., 2016). An interesting healthrelated issue is the excessive consumption of animal proteins, which means a simultaneous loss of well-being for the economy and health. Long-term consumption of animal proteins of more than $2 \%$ of the live weight may cause negative effects, especially on the digestive and cardiovascular system (WU, 2016). Moreover, obesity, which can occur due to excessive consumption of high-energy diets, is seen as a serious problem for some countries including Turkey (its prevalence in the adult population in Europe and the USA is 2-3 times that in Asia and Africa) (FAO, 2020).

As a final remark, it is necessary to mention two important facts that contradict the economic implications of this study. First, consumers in higher socioeconomic classes tend to pay higher prices for animal foods for a quality and healthy life (WILCOCK et al., 2004; SMITH, 2005; CAN et al., 2015). Searching only the cheapest products regardless of their nutritional values and structural properties can lead to consumer dissatisfaction, diseases, and serious treatment costs. Second, some animal foods such as red meat that appear disadvantageous in terms of cost-effectiveness, tend to provide longer satiety and satisfaction due to their balanced intramuscular fat distribution (SANTCHURN \& COLLIGNAN, 2007). However, since these partially justified consumer trends and behaviours do not reflect the general, the global superiority of "chicken meat and eggs" cannot be overshadowed.

\section{CONCLUSION}

The most objective indicators of animal protein consumption preferences are the price of 1 $\mathrm{g}$ protein and the purchasing power of consumers. Economic rationality for consumers refers to selecting the cheapest alternative among the alternatives of a certain quality. Although the cost-effectiveness 
and price of animal proteins vary depending on time and place due to the supply-demand balance, "chicken egg and chicken meat," which offer great economic, health, and belief advantages, maintain their importance in Turkey and in the world. If factors such as increases in population and production costs, the unpredictable course of the COVID-19 pandemic, and global climate change force nations to produce increasingly cheaper and reliable animal proteins, increases in consumer welfare can be expected in the not too distant future.

\section{DECLARATION OF CONFLICT OF INTEREST}

The authors declare there is no conflict of interests.

\section{AUTHOR'S CONTRIBUTIONS}

The planning, designing, the writing of the article, and the interpretation of the findings were conducted jointly by MFC and HYC. Data analyses of this study were performed by MFC.

\section{REFERENCES}

AYDIN, E et al. Analysis of the red meat price changes over the last 25 years and effects of import decisions in Turkey. Journal of the Turkish Veterinary Medical Society, v.82, n.1, p.3-13, 2011. Available from: < https://dergipark.org.tr/tr/pub/vetheder/ issue/34350>. Accessed: Jan. 21, 2021

BERNER, L. A. et al. Characterization of dietary protein among older adults in the United States: Amount, animal sources, and meal patterns. Journal of the Academy of Nutrition and Dietetics, v.113, n.6, p.809-815, 2013. Available from: <https://jandonline. org/article/S2212-2672(13)00096-8/pdf $>$. Accessed: May, 17, 2021. doi: $10.1016 /$ j.jand.2013.01.014.

BERRAZAGA, I. et al. The role of the anabolic properties of plantversus animal-based protein sources in supporting muscle mass maintenance: A critical review. Nutrients, v.11, n.8, 1825, 2019. Available from: <https://pubmed.ncbi.nlm.nih.gov/31394788/> Accessed: Mar. 25, 2021. doi: 10.3390/nu11081825.

BLS (U. S. Bureau of Labor Statistics). Average retail food and energy prices, Mid-Atlantic Information Office. U.S. and Midwest Region, 2021. Available from: <https://www.bls.gov/ regions/mid-atlantic/data/averageretailfoodandenergyprices usandmidwest table.htm>. Accessed: Mar. 04, 2021.

BORNER, J.; WUNDER, S. The scope for reducing emissions from forestry and agriculture in the Brazilian Amazon. Forests, v.3, n.3, p.546-572, 2012. Available from: <https://www.mdpi. com/1999-4907/3/3/546>. Accessed: May, 11, 2021. doi: 10.3390 f3030546.

CALDWELL, B. E. et al. Preliminary estimates of costeffectiveness for marital therapy. Journal of Marital and Family Therapy, v.33, n.3, p.392-405, 2007. Available from: <https:// pubmed.ncbi.nlm.nih.gov/17598785/>. Accessed: Apr. 13, 2021 doi: 10.1111/j.1752-0606.2007.00038.x.
CAN, M. F. A socioeconomic analysis of small ruminant breeders' membership relations and organizational effectiveness. Veterinary Journal of Ankara University, v.61, n.2, p.119-124, 2014. Available from: <http://vetjournal.ankara.edu.tr/tr/pub/ issue/43558/532706>. Accessed: Mar. 25, 2021. doi: 10.1501/ Vetfak_0000002615.

CAN, M. F. et al. Fish consumption preferences and factors influencing it. Food Science and Technology (Campinas), v.35, n.2, p.339-346, 2015. Available from: <https://www.scielo.br/j/ cta/a/K6J4yVtCzpKYp4hG4bRC3DS/?lang=en>. Accessed: Mar. 25, 2021. doi: 10.1590/1678-457X.6624.

CAN, M. F. The Interaction of Turkey Livestock Policies with the EU and Its Potential Outcomes. Atatürk University Journal of Veterinary Sciences, v.13, n.2, p.242-250, 2018. Available from: $<$ https://dergipark.org.tr/tr/pub/ataunivbd/issue/39963/321172>. Accessed: Apr. 19, 2021. doi: 10.17094/ataunivbd.321172.

CAN, M. F. et al. Biosecurity levels of livestock enterprises in Turkey and factors affecting these levels. Turkish Journal of Veterinary and Animal Sciences, v.44, p.632-640, 2020. Available from: <https://journals.tubitak.gov.tr/veterinary/issues/ vet-20-44-3/vet-44-3-20-1911-70.pdf>. Accessed: Mar. 25, 2021. doi: 10.3906/vet-1911-70.

CORTINA, J. M.; NOURI, H. Effect size for ANOVA designs, (Vol. 129), 2000. Thousand Oaks, CA: Sage.

FAO (Food and Agriculture Organization of the United Nations). World Food and Agriculture-Statistical Yearbook 2020. Rome, Italy, 2020. Available from: <http://www.fao.org/3/cb1329en/online/ cb1329en.html>. Accessed: Apr. 27, 2021. doi: 10.4060/cb1329en.

FOX, P. F. Cheese: An overview. In: FOX, P.F. Cheese: Chemistry, Physics and Microbiology. Boston: Springer, 1993. p.1-36.

GILBERT, O. R. Statistical methods for environmental pollution monitoring. New York: Van Nostrand Reinhold Company Inc., 1987. Available from: <https://www.osti.gov/ servlets/purl/7037501/>. Accessed: Jan. 01, 2021.

GLAUBER, J. V.; EFFLAND, A. United States agricultural policy. Its evolution and impact. IFPRI discussion paper 01543, July 2016. Available from: < http://ebrary.ifpri.org/utils/ getfile/collection/p15738coll2/id/130479/filename/130690.pdf>. Accessed: Jan. 01, 2021.

GUNLU, A. An investigation of firm concentration rate of dairy industry in raw milk marketing: A case study of Burdur province. Kafkas Universitesi Veteriner Fakultesi Dergisi, v.17, n.1, p.101-106, 2011. Available from: <http://vetdergikafkas.org/ uploads/pdf/pdf_KVFD_852.pdf $>$. Accessed: Jan. 01, 2021. doi: $10.9775 / \mathrm{kvfd} .2010 .2520$.

HART, C. E. et al. The impact of COVID-19 on Iowa's corn, soybean, ethanol, pork, and beef sectors. In: Policy briefs, 20-PB, 28. Center for Agricultural and Rural Development (CARD) at Iowa State University. Iowa, 2020. Available from: <https://www.card.iastate.edu/products/policy-briefs $>$. Accessed: Mar. 25, 2021.

HAUG, A. et al. Bovine milk in human nutrition - a review. Lipids in Health and Disease, v.6, 25, 2007. Available from: <https:// www.ncbi.nlm.nih.gov/pmc/articles/PMC2039733/>. Accessed: Feb. 15, 2021. doi: 10.1186/1476-511X-6-25. 
HOFFMAN, J. R.; FALVO, M. J. Protein - which is best? Journal of Sports Science \& Medicine, v.3, n.3, p.118-130, 2004. Available from: <https://pubmed.ncbi.nlm.nih.gov/24482589/>. Accessed: May, 11, 2021.

IANNOTTI, L. L. et al. Eggs: The uncracked potential for improving maternal and young child nutrition among the world's poor. Nutrition Reviews, v.72, n.6, p.355-368, 2014. Available from: <https:// academic.oup.com/nutritionreviews/article/72/6/355/1869975?login= true $>$. Accessed: Mar. 12, 2021. doi: 10.1111/nure.12107.

ILO (International Labour Organization). Global wage report, 202021. Wages and minimum wages in the time of COVID-19. Geneva, 2020. Available: <https://www.ilo.org/global/publications/books/ WCMS_762534/lang--en/index.htm>. Accessed: Mar. 04, 2021.

ISMAIL, B. P. et al. Protein demand: Review of plant and animal proteins used in alternative protein product development and production. Animal Frontiers, v.10 n.4, p.53-63, 2020. Available from: <https:/www.ncbi.nlm.nih.gov/pmc/articles/ PMC7759735/>. Accessed: Apr. 27, 2021. doi: 10.1093/af/vfaa040.

$\mathrm{KIM}, \mathrm{H}$. et al. A better diet quality is attributable to adequate energy intake in hemodialysis patients. Clinical Nutrition Research, v.4, n.1, p.46-55, 2015. Available from: <https://www.ncbi.nlm.nih. gov/pmc/articles/PMC4337923/>. Accessed: Mar. 25, 2021. doi: 10.7762/cnr.2015.4.1.46.

LEE, H. J. et al. Status of meat alternatives and their potential role in the future meat market-A review. Asian-Australasian Journal of Animal Science, v.33, n.10, p.1533-1543, 2020. Available from: $<$ https://www.ncbi.nlm.nih.gov/pmc/issues/364384/>. Accessed: Mar. 25, 2021. doi: 10.5713/ajas.20.0419.

MAHARJAN, S. et al. Microbial quality of poultry meat in an ISO22000:2005 certified poultry processing plant of Kathmandu valley. International Journal of Food Contamination, v.6: 8, 2019. Available from: <https://foodcontaminationjournal. biomedcentral.com/articles/10.1186/s40550-019-0078-5>. Accessed: Mar. 04, 2021. doi: 10.1186/s40550-019-0078-5.

MCCARTHY, M. et al. Factors influencing consumption of pork and poultry in the Irish market, Appetite, v.43, n.1, p.19-28, 2004 Available from: <https://pubmed.ncbi.nlm.nih.gov/15262014/>. Accessed: May, 11, 2021. doi: 10.1016/j.appet.2004.01.006.

MOHAMMED, H. H. H. et al. Comparative characterization of proximate nutritional compositions, microbial quality and safety of camel meat in relation to mutton, beef, and chicken. LWTFood Science and Technology, v.118, 108714, 2020. Available from: $\quad<$ https://www.sciencedirect.com/science/article/pii/ S0023643819310564?via\%3Dihub>. Accessed: May, 21, 2021 doi: 10.1016/j.lwt.2019.108714.

MURPHY, S. P.; ALLEN, L. H. Nutritional importance of animal source foods. The Journal of Nutrition, v.133, n.11, 3932S-3935S, 2003. Available from: $<$ https://pubmed.ncbi.nlm.nih.gov/14672292/>. Accessed: Mar. 25, 2021. doi: 10.1093/jn/133.11.3932S.

OECD (Organization for Economic Co-Operation and Development). Real minimum wages, 2021. Statistics. Available from: <https://stats.oecd.org/Index.aspx?DataSetCode=RMW $>$. Accessed: Feb. 26, 2021.

OZEN, D. et al. Modeling and forecasting meat consumption per capita in Turkey. Journal of The Faculty of Veterinary Medicine
Erciyes University, v.16, n.2, p.122-129, 2019. Available from: $<$ https://dergipark.org.tr/tr/download/article-file/773717>. Accessed: Mar. 25, 2021. doi: 10.32707/ercivet.595626.

PASIAKOS, S. M. et al. Sources and amounts of animal, dairy, and plant protein intake of US adults in 2007-2010. Nutrients, v.7, n.8, p.7058-7069, 2015. Available from: <https://www.ncbi.nlm. nih.gov/pmc/articles/PMC4555161/>. Accessed: Apr. 13, 2021. doi: $10.3390 /$ nu 7085322 .

PELLEGRINO, L. et al. Nutritional quality of milk proteins. In: MCSWEENEY, P.; FOX, P. Advanced Dairy Chemistry. 4.ed. New York: Springer, 2013. Vol. 1A: Proteins: Basic Aspects, p.515-538.

ROZENBERG, S. et al. Effects of dairy products consumption on health: benefits and beliefs-A commentary from the Belgian Bone Club and the European Society for Clinical and Economic Aspects of Osteoporosis, Osteoarthritis and Musculoskeletal Diseases. Calcified Tissue International, v.98, n.1, p.117, 2016. Available from: <https://pubmed.ncbi.nlm.nih. gov/26445771/>. Accessed: May, 11, 2021. doi: 10.1007/ s00223-015-0062-x.

SACLI, Y.; OZER, O. O. Analysis of factors affecting red meat and chicken meat consumption in Turkey using an ideal demand system model. Pakistan Journal of Agricultural Sciences, v.54, n.4, p.933-942, 2017. Available from: <https://www.researchgate. net/publication/320057273>. Accessed: Mar. 25, 2021. doi: 10.21162/PAKJAS/17.5849.

SANTCHURN, S. J.; COLLIGNAN, A. Fermented poultry sausages. In: TOLDRÁ, F. Handbook of Fermented Meat and Poultry. Iowa: Blackwell Publishing, 2007. p.361-368.

SCHMIER, J. K. et al. Single food focus dietary guidance: Lessons learned from an economic analysis of egg consumption. Cost Effectiveness and Resource Allocation, v.7, p.1-7, 2009. Available from: <https://pubmed.ncbi.nlm.nih.gov/19366457/>. Accessed: Mar. 25, 2021. doi: 10.1186/1478-7547-7-7.

SETBIR (Association of Union for Dairy, Meat, Food Industry and Producers of Turkey). Bulletin, December, 2020. Available from: <https:/www.setbir.org.tr/source/upload/belge/ hayvancilik/2021/setbir-bulten-aralik-2020.pdf>. Accessed: Feb. 08,2021 .

SMITH, V. L. Behavioral economics research and the foundations of economics. The Journal of Socio-Economics, v.34, n.2, p.135-150, 2005. Available from: <https://www.sciencedirect. com/science/article/pii/S1053535704000629>. Accessed: Feb. 08, 2021. doi: 10.1016/j.socec.2004.09.003.

SUREK, E.; UZUN, P. Alternative protein source of the future: Artificial meat. Academic Food, v.18, n.2, p.209-216, 2020. Available from: <https://dergipark.org.tr/tr/pub/akademik-gida/ issue/55310/758840>. Accessed: Feb. 08, 2021. doi: 10.24323/ akademik-gida. 758840 .

TAYAR, M.; DOGAN, M. Helal Kesim. Academic Platform Journal of Halal Life Style, v.1, n.2, p.62-76, 2019. Available from: <https://dergipark.org.tr/tr/pub/apjhls/issue/51557/649127>. Accessed: May, 11, 2021.

TEKINSEN, O. C.; TEKINSEN, K. K. Milk and milk products: Scientific grounds, technology, quality control. Konya: Selçuk University Press, 2005

Ciência Rural, v.52, n.9, 2022. 
TEPGE (Agricultural Economic and Policy Development Institute). Status and Forecast, Poultry Farming. Ankara, 2020.

TURKOMP (Turkish Food Composition Database). By foods, 2021. Available from: <http://turkomp.gov.tr/database>. Accessed: Feb. 16, 2021

TURKSTAT (Turkish Statistical Institute). Consumer price index, 2021a. Available from: <https://tuikweb.tuik.gov.tr/PreTablo. do?alt id=1014>. Accessed: Jan. 21, 2021.

TURKSTAT (Turkish Statistical Institute). Livestock statistics, 2021b. Available from. <https://tuikweb.tuik.gov.tr/PreTablo. do?alt_id=1002>. Accessed: Jan. 21, 2021.

USDA (U.S. Department of Agriculture). Food price outlook. Economic research, 2021. Available from: $<$ https://www.ers.usda. gov/data-products/food-price-outlook/>. Accessed: Feb. 22, 2021.

WILCOCK, A. et al. Consumer attitudes, knowledge and behaviour: A review of food safety issues. Trends in Food Science
\& Technology, v.15, n.2, p.56-66, 2004. Available from: <https:// citeseerx.ist.psu.edu/viewdoc/download?doi=10.1.1.1060.7132\& rep $=$ rep1\&type $=$ pdf $>$. Accessed: Mar. 25, 2021. doi: 10.1016/j. tifs.2003.08.004.

WILSON, N. et al. Cheaper than chicken: Protein foods ranked by supermarket prices. The New Zealand Medical Journal, v.120, n.1259, U2665, 2007. Available from: <https:// www.researchgate.net/publication/6117941_Cheaper_than chicken_protein_foods_ranked_by_supermarket_prices $>$. Accessed: Jan. 21, 2021.

WU, G. Dietary protein intake and human health. Food and Function, v.7, n.3, p.1251-1265, 2016. Available from: <https:// pubmed.ncbi.nlm.nih.gov/26797090/>. Accessed: Mar. 25, 2021. doi: $10.1039 / \mathrm{c} 5$ fo0 $1530 \mathrm{~h}$.

YUMBIR (Turkish Egg Producers Association). Egg prices, 2021. Available from: <https://www.yum-bir.org/Yumurta/ FiyatListele.aspx $>$. Accessed: Jan. 01, 2021. 